\title{
Production and Profitability under Contract and Non-Contract Broiler Farming Systems in Eastern Plain Zone of Uttar Pradesh, India
}

\author{
Amit Kumar Singh $^{1 *}$, M.P. Sagar ${ }^{2}$, Jitendra Pratap ${ }^{3}$ and A.K. Chaturvedani ${ }^{4}$ \\ Division of Extension Education, ICAR- Indian Veterinary Research Institute, \\ Izatnagar, Bareilly, Uttar Pradesh, India-243 122 \\ *Corresponding author
}

\begin{tabular}{|c|c|}
\hline & A B S T R A C T \\
\hline & \multirow{6}{*}{$\begin{array}{l}\text { The present study was conducted on } 120 \text { broiler farmers ( } 60 \text { contract and } 60 \text { non-contract) } \\
\text { randomly selected from four blocks of Azamgarh and Varanasi districts of Uttar Pradesh, } \\
\text { to assess and compare the production and profitability under contract and non-contract } \\
\text { broiler farming systems. The information was collected with the help of a pre-tested } \\
\text { structured interview schedule developed for the purpose. The results revealed that majority } \\
\text { of contract as well as non-contract broiler farmers had medium (4-6) production cycle per } \\
\text { year and small flock size ( } 2000-5300) \text {. The average number of production cycle per year } \\
\text { and flock size of contract broiler farmers ( } 6.27 \text { and } 4913.33) \text { was more than that of non- } \\
\text { contract broiler farmers (5.32 and } 4285) \text {. Majority of contract broiler farmers had small } \\
\text { mortality (up to } 4 \% \text { ) whereas non-contract broiler farmers had medium mortality ( } 4-6 \%) \text {. } \\
\text { The average weight of marketable birds under contract broiler farming system was } 2.08 \\
\text { kg, which was more than non-contract broiler farming system ( } 1.82 \mathrm{~kg} \text { ) and the average } \\
\text { length of production cycle under contract broiler farming systems was } 40.5 \text { days which } \\
\text { was less than non-contract broiler farming system (45.40 days). The average net return per } \\
\text { bird in non-contract broiler farming system (Rs. 12.96) was higher than contract broiler } \\
\text { farming system (Rs. } 8.11 \text { ). }\end{array}$} \\
\hline Keywords & \\
\hline $\begin{array}{l}\text { Production, } \\
\text { profitability, } \\
\text { marketable weight, } \\
\text { Length of } \\
\text { production cycle, } \\
\text { mortality. }\end{array}$ & \\
\hline Article Info & \\
\hline $\begin{array}{l}\text { Accepted: } \\
\text { 15 July } 2018 \\
\text { Available Online: } \\
10 \text { August } 2018\end{array}$ & \\
\hline & \\
\hline
\end{tabular}

\section{Introduction}

The Indian poultry sector with 7.3 per cent growth in poultry population, has witnessed one of the fastest growing sector, with annual growth of about 8 per cent in eggs and 10 per cent in meat production, over the last decade (2003-2013) amongst all animal based sectors (CARI, 2013). The high growth has placed India at $3^{\text {rd }}$ position in egg production after China and USA with a production of 75 billion eggs and $5^{\text {th }}$ position in chicken meat after USA, China, Brazil and Mexico (Kornel, 2008 ) with a production of 3.7 million metric tons of chicken meat. Poultry industry contributes about Rs. 600 billion, accounting for about 0.77 per cent of the national GDP and about 10 per cent of the livestock GDP and provides employment to over five million people in the country (CARI vision 2050). The country exported 4.3 Lac million metric tons of poultry products to the world for the worth 
of Rs. 565.87 crores during the year 2013-14 (APEDA). Despite such progress, the average per capita availability is still merely 55 eggs and $2.8 \mathrm{~kg}$ of poultry meat against the recommended level of $180 \mathrm{eggs}$ and $11 \mathrm{~kg}$ meat per annum.

Uttar Pradesh, in spite of its large human population, contributed just around 2.56 per cent of the country's poultry population. Out of the total poultry population of 18.66 million, the farm poultry constitutes 10.32 million birds (GOI, 2012).

During the period 2007-2012, poultry population in the state had grown from 17.8 millions to18.66 millions and egg production from 98.15 crores to 181.223 crores (Annual report, 2013). It is much needed to prioritize poultry development in the animal husbandry sector as egg production of the state was 181.223 crores per year, while the consumption is 473 cores per year. This huge gap in demand and supply of about 292 crores per year was met by the private sector through procuring nearly one crore eggs daily from other states. Similarly, the requirement of chicken meat was met through purchasing an approximately 10 crores day old broiler chicks from other states, annually. As per the recommendations of the Indian Nutritional Academy, Hyderabad, there should have been consumption of 182 eggs per head per annum as standard. At National level 55 eggs per person are consumed annually, while the state average is 22 eggs per person annually. Similarly, the standard suggested for chicken meat consumption is $11 \mathrm{~kg}$, while the national availability is $2.8 \mathrm{~kg}$ and for U.P, it was 0.987 $\mathrm{kg}$ per head per annum (Annual report, 2013).

A contract farming arrangement in broiler production, referred to as "chick growing agreement" is generally a wage contract between an Integrator, who supplies the intermediate inputs and procures the output, and a poultry farmer, who provides the primary inputs in the production process. The Integrator provides the growing stock (DOCs; fatteners), feed, veterinary supplies and services, and implements the final marketing of the output. The contract farmer typically provides the space and facilities (land and housing), equipment, utilities, labours (family and/or hired) and day-to-day farm management.

The farmer receives a guaranteed wage or growing charges for each live bird based on its live weight in a condition that is predetermined and agreed upon through contractual obligation (South Asia pro-poor livestock policy program, 2009). So the present study was conducted to assess the production and profitability under contract and non-contract broiler farming system and whether contract broiler farming benefitted to small farmers as compared to independent farming or it is an integrator favoured mechanism to maximize profit.

\section{Materials and Methods}

For the present study, two districts Azamgarh and Varanasi were selected purposely, out of 12 districts of the eastern plain zone of Uttar Pradesh, on the basis of poultry population. Four blocks, two from Azamgarh district (Mahrajganj and Bilariyaganj) and two from Varanasi district (Kashi Vidyapeeth and Pindra) were selected, randomly. From each block, two lists, one of contract and another of non-contract broiler farmers were prepared. Fifteen contract broiler farmers from one list and 15 non-contract broiler farmers from another list, having at least 2000 birds and two years of experience in broiler farming were selected randomly. This makes total sample size 120 broiler farmers (60 contract and 60 non-contract). Range method based on flock size was used to categories the broiler farmers into small (2000-5300 birds), medium (5300- 
8600 birds) and large (8600-12000 birds). Production in the present study was, total number of birds produced per year in different batches along with live weight, excluding mortality. It was calculated by considering the production parameters like, number of batches reared per year, the number of birds reared per batch, number of birds died per batch, length of production cycle and average marketing weight of birds. Range method was used to classify the mortality and production cycle per year into low (up to 4), medium (4-6) and high (6-8). Profitability was calculated per cycle per bird. It was measured by structured interview schedule and results were presented in terms of average, frequency, percentage and t- test was used to compare the means of contract and non-contract broiler farmers score (range method).

\section{Results and Discussion}

\section{Production under contract and non- contract broiler farming systems}

\section{Production cycle per year}

Table 1 reveals that overall, majority $(61.67 \%)$ of the broiler farmers had 4-6 production cycle per year, followed by 6-8 cycle $(23.33 \%)$ and up to 4 cycles $(15 \%)$ per year. In case of contract broiler farming system, more than fifty per cent broiler farmers $(51.67 \%)$ had taken 4-6 production cycle per year, followed by $6-8$ cycle $(43.33 \%)$ and up to 4 cycles $(5 \%)$ per year. While, majority of the non-contract broiler farmers $(71.67 \%)$ had taken 4-6 production cycle per year, followed by up to 4 cycles $(25 \%)$ and $6-8$ cycles $(3.33 \%)$ per year. The average production cycle per year of contract broiler farmers (6.27) was higher than that non-contract broiler farmer (5.32). Whereas, the overall average production cycle per year was 5.79. The t-test value indicates that there was highly significant difference between contract and non-contract broiler farmers with respect to number of batches reared per year.

\section{Flock size}

It is obvious from the table 2 that the average flock size was 4599.17 on pooled basis. Average flock size in case of contract broiler farmers was 4913, which was greater than that of non-contract broiler farmers (4285). Ramaswami et al., (2006) reported the similar findings. The study also revealed that majority $(71.67 \%)$ of the contract broiler farmers had small flock size, followed by medium (20\%) and large $(8.33 \%)$. While, in case of noncontract broiler farmers, majority $(76.67 \%)$ of them had small flock size (2000-5300), followed by medium (5300-8600, 18.33\%) and large (8600-12000, 5\%). Overall, majority $(74.17 \%)$ of the broiler farmers had small flock size, followed by medium $(19.17 \%)$ and large $(6.67 \%)$. The t-test analysis reveals that there was no significant difference between contract and non-contract broiler farmers with respect to flock size.

\section{Mortality}

Table 3 reveals that overall, 48.33 per cent of the broiler farmers had 4-6 per cent mortality, followed by up to 4 percent $(36.67 \%)$ and 6-8 percent $(15 \%)$. In case of contract broiler farmer, majority $(66.67 \%)$ of them had mortality up to 4 per cent in their farm, followed by $4-6$ per cent $(25 \%)$ and 6-8 per cent $(8.33 \%)$. While, in case of non-contract broiler farmer, majority $(71.67 \%)$ of them had 4-6 per cent mortality in their farm, followed by $6-8$ per cent $(21.67 \%)$ and up to 4 per cent $(6.67 \%)$. The average mortality at contract broiler farmers' farm (4.23\%) was lower than that of non-contract broiler farmers farm $(5.88 \%)$. Whereas, the overall mortality was 5.06 per cent. The t-test value indicates that there was highly significant difference between contract and non-contract broiler farmers with respect mortality in their farm. 
Marketable weight and length of production cycle

Table 4 depicts that the average weight of marketable birds reared under contract broiler farming system was $2.08 \mathrm{~kg}$ against noncontract broiler farmers $(1.82 \mathrm{~kg})$, which was greater than that of non-contract broiler farming system. The overall marketable weight was $1.95 \mathrm{~kg}$. The average length of production cycle of birds under contract broiler farming system was 40.56 days, which was lower than that of non-contract broiler farming system (45.40 days). Ramaswami et al., (2006), Kalamkar (2012) and Murthy et al., (2013) also reported the similar findings. The overall average length of production cycle was 42.98 days.

\section{Production}

Table 5 reveals that average flock size of small, medium and large poultry farmers, under contract and non-contract broiler farming systems were 3612 and 3339, 6958 and 6518 and 10200 and 10000 respectively. The average mortality rate was 3.8 and $4,4.1$ and 5.2 and 4.5 and 5.5 respectively. Average production cycle per year was 4.5 and $4,5.2$ and 5.4 and 6 and 5.6 respectively. Average marketable weight was 2.1 and 2.2, 2 and 1.8 and 2 and 1.95 respectively. Production per year (in quintal) was 328.39 and 282.04, 690.24 and 600.59 and 1164.60 and 1032.94 respectively.

Profitability under contract and noncontract broiler farming systems

The average cost and return under contract and non-contract broiler farming systems have been summarized in table 6 . In this study, cost items consist of variable costs (chick, feed, electricity, litter, coal and sawdust, labour, transportation charges, cost of medicine and vaccine, and other cost) and fixed costs (i.e., housing and equipments). The cost was calculated per bird per batch. The Total Cost (TC) per bird in contract and non-contract broiler farming systems were Rs 4.64 and 132.54 , respectively. In the contract broiler farming system the variable cost constituted about 76.80 per cent of total cost (excluding cost of chicks, feed, medicines, vaccines and transportation cost) of production. Among the variable cost constituents, cost of labour constituted 30.32 per cent litter18.11 per cent coal and saw dust 16.94 per cent electricity 2.63 per cent and other cost 8.83 per cent of the total cost. Cost of chicks, feed, health care services and transportation charges were provided by the Integrator hence these cost were not added in the total cost.

However, fixed cost constituted about 23.20 per cent of the total cost. Among fixed cost constituents, depreciation on building and equipment constitutes 11.99 per cent and 11.20 per cent of the total cost, respectively. While in case of non-contract broiler farming system, variable cost constituted about 99 per cent of the total cost. Among variable cost constituents, cost of chicks constituted 21.26 per cent, feed 73.97 per cent, litter 0.63 per cent, coal and saw dust 0.59 per cent, electricity 0.10 per cent, labour 1.07 per cent, transportation 0.25 per cent, medicines and vaccines 1.14 per cent, and other cost 0.30 per cent of the total cost. However, fixed cost constituted about 1 per cent of the total cost under non-contract broiler farming system. In terms of revenue, contract broiler farmers received revenue of Rs 12.74 per bird. Among revenue constituents, revenue from selling of bird constituted 90.93 per cent, selling of gunny bags 3.36 per cent, selling of manure 5.73 per cent, of the total revenue. However, in case of non-contract broiler farming system, revenue was Rs 145.10 per bird which was contributed by selling of bird (99.24\%) selling of gunny bag $(0.28 \%)$, selling of manure $(0.48 \%)$ of total revenue. 
Table.1 Distribution of broiler farmers, according to production cycle per year

\begin{tabular}{|l|c|c|c|}
\hline \multicolumn{1}{|c|}{ Production cycle per year } & C.B.F $(\mathrm{n}=60)$ & N.C.B.F $(\mathrm{n}=60)$ & Pooled $(\mathrm{N}=120)$ \\
\hline Low (up to 4) & $3(5)$ & $15(25)$ & $18(15)$ \\
\hline Medium (4-6) & $31(51.67)$ & $43(71.67)$ & $74(61.67)$ \\
\hline High (6-8) & $26(43.33)$ & $2(3.33)$ & $28(23.33)$ \\
\hline Mean \pm SD & $6.27 \pm 1.09$ & $5.32 \pm 1.27$ & $5.79 \pm 1.18$ \\
\hline t-test value & & $2.35^{*}$ & \\
\hline
\end{tabular}

Figures in the parenthesis indicate percentage. * Significant at 5\% level of significance

Table.2 Distribution of poultry farmers, according to flock size

\begin{tabular}{|l|c|c|c|}
\hline \multicolumn{1}{|c|}{ Flock size (in number) } & C.B.F $(\mathrm{n}=60)$ & N.C.B.F $(\mathrm{n}=60)$ & Pooled $(\mathrm{N}=120)$ \\
\hline Small (2000-5300) & $43(71.67)$ & $46(76.67)$ & $89(74.17)$ \\
\hline Medium (5300-8600) & $12(20.00)$ & $11(18.33)$ & $23(19.17)$ \\
\hline Large (8600-12000) & $5(8.33)$ & $3(5.00)$ & $8(6.67)$ \\
\hline Mean \pm SD & $4913.33 \pm 2484.97$ & $4285 \pm 2114$ & $4599.17 \pm 2299.49$ \\
\hline t-test value & & 0.14 & \\
\hline
\end{tabular}

Figures in the parenthesis indicate percentage.

Table.3 Distribution of broiler farmers, according to mortality of birds in their farm

\begin{tabular}{|l|c|c|c|}
\hline \multicolumn{1}{|c|}{ Mortality level (in \%) } & C.B.F $(\mathrm{n}=60)$ & N.C.B.F $(\mathrm{n}=60)$ & Pooled $(\mathrm{N}=120)$ \\
\hline Low (up to 4 percent) & $40(66.67)$ & $4(6.67)$ & $44(36.67)$ \\
\hline Medium (4-6 percent) & $15(25.00)$ & $43(71.67)$ & $58(48.33)$ \\
\hline High (6-8 percent) & $5(8.33)$ & $13(21.67)$ & $18(15.00)$ \\
\hline Mean \pm SD & $4.23 \pm 1.63$ & $5.88 \pm 1.18$ & $5.06 \pm 1.41$ \\
\hline t-test value & & $7.63 * *$ & \\
\hline
\end{tabular}

Figures in the parenthesis indicate percentage. ** Significant at $1 \%$ level of significance

Table.4 Average marketing weight and length of production cycle of birds under contract and non-contract broiler farming systems

\begin{tabular}{|l|c|c|c|}
\hline \multicolumn{1}{|c|}{ Particulars } & $\begin{array}{c}\text { C.B.F } \\
(\mathrm{n}=60)\end{array}$ & $\begin{array}{c}\text { N.C.B.F } \\
(\mathrm{n}=60)\end{array}$ & $\begin{array}{c}\text { Pooled } \\
(\mathrm{N}=120)\end{array}$ \\
\hline Average marketable weight (in kg) & $2.08 \mathrm{~kg}$ & $1.82 \mathrm{~kg}$ & $1.95 \mathrm{~kg}$ \\
\hline $\begin{array}{l}\text { Average length of production cycle (in } \\
\text { days) }\end{array}$ & 40.56 days & 45.40 days & 42.98 days \\
\hline
\end{tabular}


Table.6 Analysis of cost and benefit under contract and non-contract broiler

\begin{tabular}{|c|c|c|c|c|}
\hline \multirow{2}{*}{$\begin{array}{l}\text { Cost constituents } \\
\text { Variable cost }\end{array}$} & \multicolumn{2}{|c|}{ C.B.F $(\mathrm{N}=60)$} & \multicolumn{2}{|c|}{ N.C.B.F $(\mathrm{N}=60)$} \\
\hline & $\begin{array}{c}\text { Cost } \\
(\text { Rs/Bird) }\end{array}$ & $\begin{array}{l}\text { Percentage of total } \\
\text { cost/total revenue }\end{array}$ & $\begin{array}{c}\text { Cost } \\
(\mathbf{R s} / \text { Bird })\end{array}$ & $\begin{array}{l}\text { Percentage of total } \\
\text { cost/total revenue }\end{array}$ \\
\hline Cost of chicks & $\begin{array}{l}\text { Provided by } \\
\text { integrator }\end{array}$ & 0.0 & 28 & 21.26 \\
\hline Cost of feed & $\begin{array}{l}\text { Provided by } \\
\text { integrator }\end{array}$ & 0.0 & 98 & 73.97 \\
\hline $\begin{array}{l}\text { Electricity } \\
\text { charges }\end{array}$ & 0.12 & 2.63 & 0.132 & 0.1 \\
\hline Cost of litter & 0.84 & 18.11 & 0.83 & 0.63 \\
\hline Cost of labour & 1.41 & 30.32 & 1.42 & 1.07 \\
\hline $\begin{array}{l}\text { Cost of coal and } \\
\text { saw dust }\end{array}$ & 0.78 & 16.94 & 0.78 & 0.59 \\
\hline $\begin{array}{l}\text { Transportation } \\
\text { charges }\end{array}$ & $\begin{array}{l}\text { Provided by } \\
\text { integrator }\end{array}$ & 0.0 & 0.33 & 0.25 \\
\hline $\begin{array}{l}\text { Cost of medicine } \\
\text { and vaccine }\end{array}$ & $\begin{array}{l}\text { Provided by } \\
\text { integrator }\end{array}$ & 0.0 & 1.5 & 1.14 \\
\hline Other cost & 0.41 & 8.83 & 0.40 & 0.30 \\
\hline Total variable cost & 3.57 & 76.80 & 131.40 & 99.13 \\
\hline \multicolumn{5}{|l|}{ Fixed cost } \\
\hline $\begin{array}{l}\text { Depreciation on } \\
\text { building }\end{array}$ & 0.56 & 11.99 & 0.58 & 0.44 \\
\hline $\begin{array}{l}\text { Depreciation on } \\
\text { equipments }\end{array}$ & 0.52 & 11.20 & 0.56 & 0.43 \\
\hline Total fixed cost & 1.08 & 23.20 & 1.14 & 0.87 \\
\hline Total cost & 4.64 & & 132.54 & \\
\hline \multicolumn{5}{|l|}{ Revenue } \\
\hline $\begin{array}{l}\text { Revenue from } \\
\text { selling of birds }\end{array}$ & 11.6 & 90.93 & 144 & 99.24 \\
\hline $\begin{array}{l}\text { From selling of } \\
\text { gunny bags }\end{array}$ & 0.42 & 3.36 & 0.40 & 0.28 \\
\hline $\begin{array}{l}\text { From selling of } \\
\text { manure }\end{array}$ & 0.72 & 5.73 & 0.70 & 0.48 \\
\hline Total revenue & 12.74 & & 145.10 & \\
\hline Net return & 8.11 & & 12.56 & \\
\hline Benefit cost ratio & 2.75 & & 1.09 & \\
\hline
\end{tabular}


Table.5 Distribution of contract and non-contract broiler farmers, according to production

\begin{tabular}{|c|c|c|c|c|c|c|c|c|c|c|}
\hline \multirow[t]{2}{*}{ Flock size } & \multicolumn{2}{|c|}{$\begin{array}{l}\text { Average flock } \\
\text { size }\end{array}$} & \multicolumn{2}{|c|}{$\begin{array}{c}\text { Average } \\
\text { mortality } \%\end{array}$} & \multicolumn{2}{|c|}{$\begin{array}{c}\text { Average } \\
\text { production } \\
\text { cycle per year }\end{array}$} & \multicolumn{2}{|c|}{$\begin{array}{c}\text { Average } \\
\text { marketing } \\
\text { weight }\end{array}$} & \multicolumn{2}{|c|}{$\begin{array}{c}\text { Average } \\
\text { production per year } \\
\text { (in quintal) }\end{array}$} \\
\hline & CPF & NCPF & $\mathrm{CPF}$ & NCPF & $\mathrm{CPF}$ & NCPF & CPF & NCPF & $\mathrm{CPF}$ & NCPF \\
\hline $\begin{array}{l}\text { Small } \\
(2000- \\
5300)\end{array}$ & 3612 & 3339 & 3.8 & 4 & 4.5 & 4 & 2.1 & 2.2 & 328.39 & 282.04 \\
\hline $\begin{array}{l}\text { Medium } \\
(\mathbf{5 3 0 0 -} \\
\mathbf{8 6 0 0 )}\end{array}$ & 6958 & 6518 & 4.1 & 5.2 & 5.2 & 5.4 & 2 & 1.80 & 690.24 & 600.59 \\
\hline $\begin{array}{l}\text { Large } \\
(8600- \\
12000)\end{array}$ & 10200 & 10000 & 4.5 & 5.5 & 6 & 5.6 & 2 & 1.95 & 1164.6 & 1032.94 \\
\hline
\end{tabular}

Net return per bird under contract broiler farming system (Rs 8.11/bird) was lower than non-contract broiler farming system (Rs12.56/bird). Kalamkar (2012) and Kakade et al., (2014) also reported the similar findings. The benefit-cost ratio in contract and non-contract broiler farming systems were 2.75 and 1.09 respectively, which indicates that contract broiler farming system was more profitable than non- contract broiler farming system.

In conclusion, the study has assessed and compares the production and profitability under contract and non contract broiler farming systems. Analysis of data revealed that Majority of the broiler farmers had 4-6 production cycle per year, small flock size and 4-6 per cent mortality. The average marketable weight and length of production cycle were $1.98 \mathrm{~kg}$ and 42.98 days, respectively. The average net return per $\mathrm{kg}$ of live weight as well as per bird was higher in non-contract group than contract group. Contract broiler farming system had better production in comparison to non-contract broiler farming system, because contract system has shorter length of production cycle, more average marketing weight and less mortality in comparison to non-contract broiler farming system. Therefore, it should be promoted in other areas also.

\section{References}

APEDA. 2013. Agricultural and Processed Food Products Export Development Authority, Animal Products. http://apeda.gov.in/apedawebsite/six _ head_product/animal.htm

CARI. 2013. Central Avian Research Institute, Perspective Plan Vision 2050

Kakade, V. B., Suryavanshi, S.S., Shikalgar, A. A., 2012. Employment and income generation under contract farming: a case study of poultry: In $54^{\text {th }}$ Annual Conference the Indian Society of Labour Economics.

Kalamkar, S.S. 2012. Inputs and services delivery system under contract farming: a case of poultry farming. J. Agr. Econ. Res., 25: 515-21.

Kornel, D. 2008. Poultry Sector Country Review, Food and Agriculture Organization of the United Nations, Animal Production and Health 
Division, September.

Murthy, S., Madhuri, B. 2013. A case study on Suguna poultry production through contract farming in Andhra Pradesh. Asia. Pac. J. Market. Manage., 2 (5): 58-68.

GOI. 2012. Nineteenth livestock census all India report. Ministry of Agriculture Department of Animal Husbandry, Dairying and Fisheries Krishi Bhawan, New Delhi.
Ramaswami, B., Birthal, P.S. and Joshi, P.K. 2006. Efficiency and distribution in contract farming: The case of Indian poultry growers. MTID discussion papers, 91, markets, trade, and institutions division, Washington, DC, international food policy research institute.

Annual report. 2013. State department of animal husbandry, Uttar Pradesh.

\section{How to cite this article:}

Amit Kumar Singh, M.P. Sagar, Jitendra Pratap and Chaturvedani, A.K. 2018. Production and Profitability under Contract and Non-Contract Broiler Farming Systems in Eastern Plain Zone of Uttar Pradesh, India. Int.J.Curr.Microbiol.App.Sci. 7(08): 2624-2631.

.doi: https://doi.org/10.20546/ijcmas.2018.708.270 